\title{
PERLINDUNGAN HUKUM BAGI PENGEMUDI TRANSPORTASI AKIBAT PEMBATALAN SEPIHAK OLEH KONSUMEN
}

\author{
Yandri Radhi Anadi \\ Fakultas Hukum Universitas Islam Malang, Indonesia \\ E-mail: yandri@unisma.ac.id
}

\begin{abstract}
Abstrak
Tujuan penelitian ini adalah untuk mengkaji tentang perlindungan hukum bagi pengemudi transportasi akibat pembatalan sepihak oleh konsumen karena dalam praktiknya kegiatan pesan memesan makanan lewat ojek online ini masih sering mengalami banyak kendala. Salah satunya adalah adanya pembatalan pesanan yang dilakukan secara sepihak oleh konsumen. Metode penelitian yang digunakan adalah metode penelitian hukum normatif dengan menggunakan metode pendekatan perundang-undangan (statute approach) dan pendekatan konseptual (conseptual approach). Berdasarkan hasil penelitian bahwa Pembatalan pesanan secara sepihak oleh konsumen tentu tidak berdampak terhadap konsumen, namun berdampak bagi pengemudi ojek online tersebut. Kerugian dalam bentuk materiil tentu masih bisa diganti, tetapi kerugian immateriil tidak akan bisa diganti. Pembatalan sepihak oleh konsumen tersebut merupakan suatu perbuatan pelanggaran hukum yang harus di pertanggungjawabkan oleh konsumen, bentuk perlindungan yang didapatkan oleh pengemudi ojek online adalah memberikan biaya ganti kerugian sebagaimana yang terdapat dalam ketentuan pasal 1365 KUHPerdata. Dalam ketentuan yang diberikan oleh undang-undang untuk perlindungan hukum kepada pengemudi ojek online harus mempunyai itikad yang baik bagi konsumen untuk mengembalikan kerugian yang sudah dialami oleh pengemudi ojek online.
\end{abstract}

Kata Kunci: Perlindungan Hukum; Pembatalan Pesanan; Konsumen.

\begin{abstract}
The purpose of this study was to examine the legal protection for transportation drivers due to unilateral cancellation by consumers because in practice, ordering food through online motorbikes often experiences many obstacles. One of them is the order cancellation made unilaterally by consumers. The research method used is a normative legal research method using a statute approach and a conceptual approach. Based on the results of the research that the cancellation of orders unilaterally by consumers certainly does not have an impact on consumers, but it has an impact on the online motorcycle taxi drivers. Losses in material form of course can still be replaced, but immaterial losses cannot be replaced. The unilateral cancellation by the consumer is a violation of the law that must be held accountable by the consumer, the form of protection obtained by online motorcycle taxi drivers is to provide compensation costs as contained in the provisions of article 1365 of the Civil Code. In the provisions provided by the law for legal protection to online motorcycle taxi drivers, they must have good faith for consumers to return the losses that have been experienced by online motorcycle taxi drivers.
\end{abstract}

Keywords: Legal protection; Cancellation Order; Consumer.

\section{A. PENDAHULUAN}

Manusia sebagai mahluk sosial mempunyai banyak kebutuhan yang harus dipenuhi untuk kesejahteraan hidupnya. Kebutuhan tersebut dimungkinkan tidak dapat terpenuhi dalam satu lokasi. Oleh karena itu manusia memerlukan transportasi untuk melakukan perpindahan orang dan/atau barang dari satu tempat ketempat yang lain dengan menggunakan kendaraan. ${ }^{1}$ Kemajuan teknologi merupakan sebuah keniscayaan yang mau tidak mau harus kita ikuti.

${ }^{1}$ Abbas Salim.(2000). Manajemen Transportasi. Jakarta: PT Raja Grafindo Persada, hlm. 45. 
Jasa merupakan objek transaksi bisnis yang tergolong sangat populer apalagi di era sistem elektronik yang semakin canggih. Pelayanan jasa sudah semakin banyak yang ditopang dengan sistem online, salah satunya adalah bisnis jasa angkutan. ${ }^{2}$

Transportasi adalah pengangkutan barang dan orang menggunakan kendaraan sesuai dengan yang dibutuhkan. Selain itu Transportasi atau angkutan adalah perpindahan orang dan/atau barang dari satu tempat ke tempat lain dengan menggunakan Kendaraan di Ruang Lalu Lintas. ${ }^{3}$ Yang dimaksud kendaraan menurut Pasal 1 angka 7 "Kendaraan adalah suatu sarana angkut di jalan yang terdiri atas kendaraan bermotor dan kendaraan tidak bermotor." Sejauh ini transportasi sudah mengalami kemajuan yang pesat. Berbagai macam transportasi muncul untuk memudahkan kehidupan masyarakat. Mulai dari bus, angkutan kota, kereta api, hingga layanan transportasi yang berbasis online. Tiap moda tranportasi mempunyai sifat, karakteristik dan aspek teknis yang berlainan, yang akan memengaruhi jasa-jasa angkutan yang akan ditawarkan oleh pengangkutan. ${ }^{4}$

Transportasi online adalah perusahan transportasi yang menggunakan aplikasi sebagai penghubung antara pengguna dan pengemudi yang sangat mempermudah pemesanan, selain itu juga tarif perjalanan sudah langsung bisa dilihat pada aplikasi. Kegiatan dari transportasi adalah memindahkan barang (commodity of goods) dan penumpang dari satu tempat (origin atau port of call) ke tempat lain (part of destination), maka dengan demikian pengangkutan menghasilkan jasa angkutan atau dengan kata lain produksi jasa bagi masyarakat yang membutuhkan sangat bermanfaat untuk memindahkan atau pengiriman barangnya. ${ }^{5}$

Seiring berkembangnya teknologi, kehidupan masyarakat juga berkembang menjadi lebih baik. Adannya kebutuhan dasar mnausia yaitu kebutuhan pangan sebagai salah satu kebutuhan sehari-hari yang harus dipenuhi, maka seseorang harus menyiapkan kebutuhan pangan atau makananya sendiri. Dalam hal ini kita harus mengurus menyiapkan segalanya sendiri termasuk membeli bahan makanan. Namun, mengingat bahwa sekarang teknologi semakin canggih dan salah satu dampak perkembangan teknologi adalah munculnya berbagai macam layanan transportasi berbasis online seperti ojek online atau yang sering disebut ojol. Keberadaannya dinilai dapat membantu mobilitas masyarakat modern yang serba praktis ini. Ojol menyediakan berbagai fitur layanan, salah satunya adalah layanan pengantaran makanan. Layanan pengantar makanan ini banyak digemari oleh masyarakat karena cara memesan atau ordernya gampang dan mudah dipahami, tidak perlu keluar rumah makanan akan sampai dirumah. Kemudian sistim transaksi untuk membayar makanna yang siap antarpun juga melalui online atau bisa cash ketika makanna smapai dirumah. Dengan memiliki fitur layanan pengantar makanan yang dimiliki oleh ojol membuat masyarakat gemar memesan dan memberikan suatu kenyamanan tersendiri bagi masyarakat atau konsumen, terlebih lagi dimasa pandemi covid-19 ini, hal ini merupakan salah satu cara yang sangat baik untuk digunakan. Meskipun dinilai meringankan kehidupan masyarakat, namun dalam praktiknya masih sering terjadi hambatan dalam bentuk pesanan konsumen yang tidak bertanggung jawab. Yaitu adanya pesanan fiktif dan pembatalan pesanan ketika makanan sudah dibeli oleh pengemudi.

Padahal di dalam ketentuan aplikasi penggunaanya sudah dicantumkan syarat dan ketentuan bagi konsumen. Sebagai contoh dan informasi, dalam angka 2 huruf f Syarat dan Ketentuan Go Food yang berbunyi: "Anda hanya dapat melakukan pembatalan atas Transaksi sebelum Mitra melakukan pembelian produk.”. ${ }^{6}$ Yang disebut sebagai mitra dalam ketentuan diatas

\footnotetext{
${ }^{2}$ Agustinus Simanjuntak.(2018). Hukum Bisnis Sebuah Pemahaman Integratif antar Hukum dan Praktik Bisnis. Depok: Rajawali Pers, hlm. 82.

${ }^{3}$ UU No.22 Tahun 2009 tentang Lalu Lintas dan Angkutan Jalan

${ }^{4}$ Abbas Salim, op.cit., hlm. 18.

${ }^{5}$ Soegjitna Tjakranegara.(1995). Hukum Pengangkutan Barang Dan Penumpang. Jakarta: Rineka Cipta, hlm. 1

${ }^{6}$ Syarat dan Ketentuan Penggunaan GoFood, Diakses pada tanggal 22 April 2020, Website: gojek.com/terms-and-condition/
}

116 Yandri Radhi | Perlindungan Hukum Bagi... 
adalah pengemudi ojek online. Hubungan yang timbul antara pengemudi ojek online dengan konsumen adalah penyedia layanan jasa dengan konsumen. Selain itu, pemesanan makanan atau minuman melalui aplikasi telah memunculkan adanya perikatan antara pengemudi dengan konsumen seperti yang tercantum dalam Pasal 1338 Burgerlijk Wetboek(BW) tentang Perjanjian.

Apabila konsumen membatalkan pesanan setelah pengemudi membeli maka telah melanggar Pasal 1338 tersebut. Pengemudi juga dapat melakukan gugatan atau tuntutan ganti rugi terhadap konsumen yang melanggar perjanjian sesuai dengan Pasal 1243 BW. Ganti rugi dapat timbul salah satunya karena wanprestasi, sebagaimana wanprestasi (kelalaian/kealpaan) seorang debitur dapat berupa: ${ }^{7}$

1. Tidak melakukan apa yang disanggupi akan dilakukannya.

2. Melaksanakan apa yang dijanjikannya, tetapi tidak sebagaimana dijanjikan.

3. Melakukan apa yang dijanjikannya tetapi terlambat.

4. Melakukan sesuatu yang menurut perjanjian tidak boleh dilakukan.

Dengan demikian, dalam sebuah peraturan yang terdapat untuk menunjang pengaturan yang dipakai dalam menuntukan suatu perbuatan pelanggaran oleh setiap individu yang dalam hal ini berkaitan dengan pengemudi transportasi dalam pembatalan sepihak oleh konsumennya yang dewasa ini banyak yang terjadi dalam lingkungan sosial bermasyarakat. Untuk itu, dalam memperkuat perlindungan hukum yang diberikan terhadap pihak yang dirugikan perlunya peneliti menggunakan teori sebagai pandangan sistematik mengenai fenomena yang terjadi, maka teori yang dipakai yaitu teori kepastian hukum dan teori perlindungan hukum.

Berdasarkan penjelasan diatas maka wanprestasi yang dilakukan oleh konsumen yang melakukan pembatan secara sepihak adalah terdapat pada point a dan d. Konsumen tidak melakukan apa yang disanggupi akan dilakukannya, dalam hal ini apabila konsumen memesan makanan melalui aplikasi ojek online maka konsumen juga menyanggupi akan membayar sesuai ketentuan. Dan konsumen juga telah melakukan sesuatu yang menurut perjanjian tidak boleh dilakukan yang maksudnya konsumen tidak boleh membatalkan pesanan secara sepihak sesuai perjanjian.

Lalu bagaimana perlindungan hukum bagi pengemudi transportasi online akibat pembatalan sepihak oleh konsumen? Dengan demikian peneliti tertarik untuk mengkaji hal tersebut, dengan judu bahasan "Perlindungan Hukum Bagi Pengemudi Transportasi Akibat Pembatalan Sepihak Oleh Konsumen"

\section{B. METODE PENELITIAN}

Metode yang digunakan adalah yuridis normatif. Yuridis normatif atau penelitian hukum normatif adalah penelitian yang berfokus pada norma-norma hukum yang berlaku dan pengkajian norma-norma hukum tersebut dilakukan dengan cara meneliti bahan hukum sekunder sebagai bahan utama, sedangkan bahan hukum primer sebagai penunjang. Penelitian ini menggunakan 2 macam pendekatan, yakni pendekatan perundang-undangan (statute approach) dan pendekatan konseptual (conseptual approach).

Pendekatan Perundang-Undangan ( statute approach), adalah pendekatan yang menggunakan berbagai aturan hukum yang menjadi fokus dan menerapkan tema setral suatu penelitian. Maka dari itu penelitian harus melihat hukum sebagai sistem tertutup yang mempunyai sifat comprehensive, all-inclusive, dan systematic. Sedangkan Pendekatan Konseptual (conseptual approach) adalah pendekatan yang dilakukan untuk memeriksa secara konseptual atas makna yang dikandung oleh istilah-istilah yang digunakan dalam aturan perundang-undangan, serta menelaah terkait kasus yang dialami oleh peneliti. Dengan demikian, dapat dikatakan bahwa

${ }^{7}$ Subekti, I. (1984). Hukum Perjanjian. Jakarta: PT Intermasa, hlm. 45. 
pada dasarnya tugas konseptual hukum adalah menelaah pengertian hukum, asas hukum, kaidah hukum, sistem hukum, dan berbagai konsep yuridik. ${ }^{8}$

Penelitian ini adalah penelitian kepustakaan. Bahan hukum yang dihimpun dalam penelitian ini dihasilkan dari studi kepustakaan. Studi kepustakaan dilakukan dengan cara mempelajari dan memahami buku-buku, peraturan perundang-undangan dan pendapat-pendapat yang berkaitan dengan penelitan ini.

\section{PEMBAHASAN}

\section{Perlindungan Hukum Bagi Pengemudi Transportasi Online Akibat Pembatalan Sepihak Oleh Konsumen}

Semakin tingginya tuntutan mobilitas masyarakat di zaman modern ini, tentunya membutuhkan sarana transportasi yang dapat mengimbangi pergerakan masyarakat yang serba cepat dan instan. Adanya terobosan baru dibidang sarana transportasi yang menggabungkan jasa transportasi dengan teknologi komunikasi bagaikan angin segar bagi kehidupan masyarakat yang dinamis ini. Kemajuan teknologi yang tergolong pesat tentunya semakin memudahkan mobilitas masyarakat. Salah satu contoh kemajuan teknologi dibidang transportasi adalah adanya layanan transportasi berbasis online atau ojek online.

Berdasarkan Undang-Undang Nomor 22 Tahun 2009 tentang Lalu Lintas dan Angkutan Jalan Pasal 1 Angka 10 menyatakan bahwa: "Kendaraan Bermotor Umum adalah setiap kendaraan yang digunakan untuk angkutan barang dan/atau orang dengan dipungut biaya". Sedangkan berdasarkan Pasal 1 Angka 20 Undang-Undang Lalu Lintas dan Angkutan Jalan menyatakan: "Sepeda motor adalah kendaraan bermotor roda dua dengan atau tanpa rumahrumah dan dengan atau tanpa kereta samping atau kendaraan bermotor roda tiga tanpa rumahrumah."

Ojek online adalah moda transportasi di era modern yang mengedepankan teknologi. Kelebihan ojek online daripada ojek konvensional adalalah konsumen tidak perlu repot untuk datang ke pangkalan ojek atau menunggu ojek konvensional lewat. Namun bisa langsung memesan lewat aplikasi. Penggunaan ojek memang lebih praktis. Penggunaan moda transportasi umum ini juga bisa membantu sedikit mengurangi kemacetan dibandingkan membawa kendaraan pribadi. Selain untuk pengangkutan orang dan juga barang, ojek online juga memiliki layanan lain yang tidak dimiliki oleh ojek konvensional. Yaitu layanan pengantaran makanan.

Transportasi online adalah perusahaan transportasi yang menggunakan aplikasi sebagai penghubung antara pengguna dan pengemudi yang sangat mempermudah pemesanan, selain itu juga tarif perjalanan sudah langsung bisa dilihat pada aplikasi. Kegiaatan dari transportasi adalah memindahkan barang (commodity of goods) dan penumpang dari satu tempat (origin atau part of call) ke tempat lain (part of destination), maka dengan demikian pengangkutan menghasilkan jasa angkutan atau dengan kata lain produksi jasa bagi masyarakat yang membutuhkan sangat bermanfaat untuk memindahkan atau pengiriman barangnya. ${ }^{10}$

Ojek online sebagai sarana transportasi modern berbasis teknologi dinilai lebih praktis dan efisien. Konsumen tidak perlu repot menunggu. Bahkan bisa memesan kapanpun dan dimanapun asalkan ada jaringan internet. Waktu beroperasinya angkutan online inipun berbeda dengan angkutan konvensional yang terbatas. Dengan adanya angkutan ini, konsumen tidak perlu khawatir akan tertinggal maupun terlewatkan. Ojek online adalah perusahaan jasa.

\footnotetext{
${ }^{8}$ Joenedi Efendi dan Jhonny Ibrahim.(2018). Metode Penelitian Hukum Normatif dan Empiris. Depok: Pernadamedia Group, hlm. 132.

${ }^{9}$ Undang-Undang Nomor 22 Tahun 2009 tentang Lalu Lintas dan Angkutan Jalan

${ }^{10}$ Tjakranegara R. Soegijatno, op.cit., Hlm. 1.
} 
Perdagangan dan jasa berdasarkan Undang-Undang Nomor 7 Tahun 2014 tentang Perdagangan diartikan sebagai "tatanan kegiatan yang terkait dengan transaksi barang dan/atau jasa di dalam negeri dan hak atas barang dan/atau jasa untuk memperoleh imbalan atau kompensasi.".11

Fenomena banyaknya transportasi online salah satunya yaitu ojek online memiliki berbagai dampak, diantaranya tampaknya disini konsumenlah yang paling diuntungkan dan memiliki kemudahan dalam mengaksesnya. Ketersediaan berbagai aplikasi transportasi online memudahkan mereka untuk memilih moda transportasi apa saja yang ingin digunakannya, bahkan melakukan berbagai transaksipun dalam pembayaran transportasi online. berkembangnya moda transportasi online membuat pelaku usaha ingin terus mengembangkan bisnis dibidang transportasi online yangg sekarang gemar diminati oleh masyarakat.

Dalam pandangan terkait dengan jasa dan barang terdapat perbedaan didalmnya, yang antara lain: ${ }^{12}$

1. Tidak berwujud (intangibility) Jasa bersifat intangible, artinya adalah sesuatu yang tidak berwujud. Jasa tidak dapat dilihat, dirasa, didengar, atau dicium sebelum jasa itu dibeli. Jika benda merupakan obyek, alat atau benda yang bisa dinilai dari bentuk dan fungsinya, maka jasa adalah suatu perbuatan (pelayanan), kinerja (performance) atau usaha.

2. Tidakdapatdipisahkan(inseperability)Jasaumumnyadijualdulubarukemudiandiproduksi secara khusus dan dikonsumsi pada waktu yang bersamaan. Mutu / kualitas dari suatu jasa terjadi pada saat pemberian jasa. Interaksi yang terjadi antara penyedia jasa dan konsumen menjadi ciri khusus dan sangat berpengaruh terhadap mutu dari jasa yang diberikan. Artinya, konsumen juga terlibat secara langsung atau tidak langsung dalam proses produksi. Keduanya mempengaruhi hasil (outcome) dari jasa tersebut.

3. Keragaman (variability) Jasa bersifat sangat beragam karena merupakan nonstandardized out-put. Artinya ada banyak variasi jenis dan kualitas tergantung pada siapa (who), kapan (when), dan di mana (where) jasa tersebut dihasilkan.

4. Tidak tahan lama (perishability) Jasa memiliki karakteristik tak tahan lama dan tidak dapat disimpan karena sifatnya yang tidak berwujud fisik. (Untuk jenis jasa tertentu karakteristik ini tidak berlaku. Terutama untuk jasa pembuatan barang fisik seperti, jasa las pagar / kanopi, jasa jahit baju, fotografi dll).

Secara garis besar, layanan yang tersedia dalam aplikasi online yang ditawarkan adalah : ${ }^{13}$

1. Layanan transportasi antar jemput baik dengan sepeda motor ataupun mobil. Dari jenis layanan ini melibatkan tiga pihak yaitu perusahaan,penyedia layanan atau pengemudi dan konsumen.

2. Layanan pesan antarmakanan secara online dengan pilihan berbagai makanan dari berbagai restoran yang sudah terdaftar dalam aplikasi. Jenis layanan ini melibatkan tiga pihak dalam transaksi yaitu perusahaan aplikasi,penyedia layanan, restoran,dan konsumen.

3. Layanan pesan antar belanja dari berbagai daftar toko dan produk belanja. Dari skema transaksi ini terlibat empat pihak yaitu perusahaan, penyedia layanan, toko dan konsumen. Layanan pindah barang. Dengan memilih fitur layanan ini, penyedia layanan akan datang untukmengangkutbarangyangakandipindahkanketempattujuan. Transaksiinimelibatkan tiga pihak yaitu perusahaa, penyedia layanan dan konsumen.

4. Layanan jasa kebersihan professional. Apabila konsumen menggunakan fitur ini maka perusahaan akan menghubungkan dengan penjual jasa kebersihan yang akan langsung datang ke alamat konsumen. Ada tiga pihak dalam transaksi ini yaitu perusahaan, penjual jasa tenaga kebersihan dan konsumen,

\footnotetext{
${ }^{11}$ Undang-Undang Nomor 7 Tahun 2014 tentang Perdagangan

${ }^{12}$ Fandy Tjiptono.(2000). Manajemen Jasa, Edisi Ke-2. Yogyakarta: Andy Offset, hlm. 15-18.

${ }^{13}$ Dian Mandayani Ananda Nasution, April 2018, Tinjauan Hukum Terhadap Layanan Transaksi dan Transportasi Berbasis Aplikais Online, Resam Jurnal hukum, Vol. 4, No. 1, Hlm. 24-25.
} 
5. Layanan pindah barang. Dengan memilih fitur layanan ini, penyedia layanan akan datang untukmengangkutbarangyangakandipindahkanketempattujuan. Transaksiinimelibatkan tiga pihak yaitu perusahaa, penyedia layanan dan konsumen.

6. Layanan pijat kesehatan professional. Disini Perusahaan aplikasi akan menghubungkan konsumen dengan penjual jasa pijat. Ada tiga pihak dalam transaksi ini yaitu perusahaan, penjual jasa dan konsumen.

7. Layanan jasa kebersihan professional. Apabila konsumen menggunakan fitur ini maka perusahaan akan menghubungkan dengan penjual jasa kebersihan yang akan langsung datang ke alamat konsumen. Ada tiga pihak dalam transaksi ini yaitu perusahaan, penjual jasa tenaga kebersihan dan konsumen.

8. Layanan jasa perawatan kecantikan. Fitur ini mekanismenya sama dengan layanan jasa kebersihan yang meibatkan tiga pihak yaitu perusahaan, salon virtual dan konsumen.

9. Layanan pesan antar tiket ke tangan pelanggan mulai dari tiket konser, olahraga dan lainlain. Pada fitur ini, penyedia layanan atau pengemudi berdasarkan pesanan konsumen akan melakukan pembelian tiket untuk konsumen dan menyerahkannya pada konsumen dengan menerima biaya atau jasa titip beli. Ada empat pihak dalam fitur ini yaitu perusahaan, penyedia layanan, penjual tiket dan konsumen.

10. Layanan pengisian ulang pulsa langsung dari aplikasi. Fitur ini hanya antara perusahaan aplikasi dengan konsumen. Pengisian pulsa langsung tanpa perantara penyedia layanan.

Dalam hal pelayanan, ojek online menyediakan beberapa fitur layanan. Salah satunya adalah jasa pengantaran makanan. Penggunaan layanan pemesanan makanan melalui ojek online ini pun sangat mudah. Konsumen hanya perlu memilih makanan seperti apa yang ingin dipesan kemudian memilih restoran yang sudah bekerjasama dengan ojek online. Setelah itu pengemudi ojek online akan mencarikannya sesuai dengan keinginan dari konsumen. Konsumen tidak perlu repot lagi dengan pergi sendiri ke restoran untuk membeli makanan yang sedang diinginkan.

Pemesanan makanan melalui aplikasi telah melahirkan hubungan perdata antara konsumen dan pengemudi ojek online, yaitu suatu perjanjian. Pengertian perjanjian atau perikatan menurut Subekti adalah suatu perjanjian merupakan suatu peristiwa di mana seseorang berjanji kepada orang lain, atau di mana dua orang saling berjanji untuk melaksanakan sesuatu hal. ${ }^{14}$ Pasal 1313 BW, "suatu persetujuan adalah suatu perbuatan dengan mana satu orang atau lebih mengikatkan dirinya terhadap satu orang lain atau lebih."15

Semua perjanjian yang dibuat secara sah berlaku sebagai undang-undang bagi mereka yang membuatnya. Suatu perjanjian tidak dapat diatarik kembali selain dengan sepakat kedua belah pihak, atau karena alasan-alasan yang oleh undang-undang dinyatakan cukup untuk itu. Suatu perjanjian harus dilaksanakan dengan itikad baik. ${ }^{16}$ Syarat sahnya perjajian menurut Pasal 1320 BW yaitu:

1. Sepakat mereka yang mengikatkan dirinya.

2. Kecakapan untuk membuat suatu perikatan.

3. Suatu hal tertentu.

4. Suatu sebab yang halal.

Sebagaimana yang menjadi subjek dan objek perjanjian, menurut Wirjono Prodjodikoro bahwa tiap-tiap perjanjian ada dua macam subjek, yaitu ke-1 seorang manusia atau suatu badan hukum yang mendapat beban kewajiban untuk sesuatu, ke-2 seorang manusia atau suatu badan hukum yang mendapat hak atas pelaksanaan kewajiban itu ${ }^{17}$ Transaksi berbasis aplikasi online

\footnotetext{
${ }^{14}$ Subekti, II.(2001). Pokok-Pokok Hukum Perdata. Jakarta: PT. Intermasa, hlm. 36.

${ }^{15}$ Pasal 1313 Kitab Undang-Undang Hukum Perdata.

${ }^{16}$ Pasal 1338 Kitab Undang-Undang Hukum Perdata.

${ }^{17}$ Wirjono Prodjodikoro.(2011). Azaz-Azaz Hukum Perjanjian. Bandung: Mandar Maju, hlm. 78.
} 
pada hakekatnya adalah sebuah perikatan. Sebagaimana definisi perikatan yang dikemukakan oleh Subekti, bahwa suatu perikatan adalah suatu perhubungan hukum antara dua orang atau dua pihak, berdasarkan mana pihak yang satu berhak menuntut sesuatu hal dari pihak yang lain, dan pihak yang lain berkewajiban untuk memenuhi tuntutan itu. ${ }^{18}$

Pengemudi ojek online dikategorikan sebagai pelaku usaha karena hubungan antara pengemudi Go-jek dengan go-jek adalah mitra. Hubungan kemitraan antara keduanya dicantumkan didalam "Perjanjian Kerjasama Kemitraan oleh go-jek Indonesia." Selain itu pasal 1 ayat 3 Undang-undang No. 8 Tahu 1999 Tentang Perlindungan Konsumen memberikan pengertian bahwa pelaku usaha adalah setiap perseorangan atau badan usaha, baik yang berbentuk badan hukum maupun bukan badan hukum yang didirikan dan berkedukan atau melakukan kegiatan dalam wilayah hukum Negara Republik Indonesia, baik sendiri maupun bersama-sama melalui perjanjian penyelenggaraan kegiatan usaha dalam berbagai bidang ekonomi." 19

Namun dalam praktiknya masih sering terjadi adanya pembatalan yang dilakukan secara sepihak oleh konsumen. Sebagai contoh kasus yang terjadi di Kota Semarang, seorang konsumen yang membatalkan pesanannya secara sepihak. Dan lebih parahnya lagi konsumen tersebut memberikan 1 bintang kuning kepada si driver gojek. Dan akibat dari hal tersebut si driver gojek itu mendapat peringatan dari perusahaan Go-Jek cabang Semarang. Driver tersebut lantas menelpon konsumen untuk meminta pertanggung jawaban tetapi konsumen berusaha untuk tidak menanggapi permintaan pertanggungjawaban tersebut. Hal tersebut sangat merugikan pihak driver Go-Jek.

Pembatalan pesanan yang dilakukan secara sepihak oleh konsumen tidak sesuai dengan Undang-Undang Nomor 8 Tahun 1999 tentang Perlindungan Konsumen yang menjelaskan kewajiban konsumen, yaitu:

1. Membaca atau mengikuti petunjuk informasi dan prosedur pemakaian.

2. Beritikad baik dalam melakukan transaksi pembelian barang dan/atau jasa.

3. Membayar sesuai dengan nilai tukar yang disepakati.

4. Mengikuti upaya penyelesaian hukum sengketa perlindungan konsumen secara patut. ${ }^{20}$

Tidak dipenuhinya kewajiban konsumen ini merupakan bentuk dari kelalaian atau wanprestasi terhadap ojol. Konsumen tidak mengikuti informasi denganbaik sebelum melakukan pemesanan makanan, dimana yang seharusnya dalam angka 2 huruf f Syarat dan Ketentuan Go Food yang berbunyi: "Anda hanya dapat melakukan pembatalan atas Transaksi sebelum Mitra melakukan pembelian produk." tersebut tidak seharusnya dilakukan. Kemudian pada pasal 1338 KUHPdt mengatakan "semua persetujuan yang dibuat sesuai dengan undnagundang berlaku bagi mereka yang membuatknya. Persetujuan itu tidak dapat ditarik kembali selain dengan kesepakatan kedua belah pihak, atau karena alasan-alasan yang ditentukan oleh undnag-undnag. Persetujuan harus dilaksanakan dengan itikad baik." Kepada konsumen diharapkan dapat bijak dalam hal ini. Kemudian, saat terjadinya pembatalan pemesanan makanan, konsumen tidak ada niatan untuk mengganti rugi, hal ini juga bertentangan dengan itikad baik dalam melakukan pembelian barang. Lalu, saat hal ini benar-benar disengketakan konsumen tidak mau tau dan tidak mengikuti upaya penyelesain senegketa.

Sedangkan hak yang dipersamakan dengan pelaku usaha yang dalam hal ini bisa dikatakan pengemudi ojek onlie, sebagaiamana berdasarkan ketentuan Undang-Undang Nomor 8 Tahun 1999 tentang Perlindungan Konsumen adalah: ${ }^{21}$

\footnotetext{
${ }^{18}$ Subekti, I, op.cit., hlm. 1

${ }^{19}$ Pasal 1 ayat 3 Undang-undnag No. 8 Tahun 1999 Tentang Perlindungan Konsumen.

${ }^{20}$ Pasal 5 Undang-Undang Nomor 8 Tahun 1999 tentang Perlindungan Konsumen.

${ }^{21}$ Pasal 6 Undang-Undang Nomor 8 Tahun 1999 tentang Perlindungan Konsumen.
} 
1. Hak untuk menerima pembayaran yang sesuai dengan kesepakatan mengenai kondisi dan nilai tukar barang dan/atau jasa yang diperdagangkan.

2. Hak untuk mendapatkan perlindungan hukum dari konsumen yang beriktikad tidak baik.

3. Hak untuk melakukan pembelaan diri sepatutnya di dalam penyelesaian hukum sengketa konsumen.

4. Hak untuk rehabilitasi nama baik apabila terbukti secara hukum bahwa kerugian konsumen tidak diakibatkan oleh barang dan/atau jasa yang diperdagangkan.

5. Hak-hak yang diatur dalam ketentuan peraturan perundang-undangan lainnya.

Hak pengemudi ojek online pada poit no 1 yaitu pengemudi ojek online berhak untuk menerima pembayaran yang sesuai dengan kesepakatan mengenai kondisi dan nilai tukar barang dan/atau jasa yang diperdagangkan. Perbuatan konsumen yang acuh tak acuh dengan seenaknya membatalkan pembayaran sesuai pesanan yang telah disepakati sebelumnya telah melanggar hak pengemudi ojek online. Point ke 2 yaitu pengemudi online juga berhak mendapatkan perlindungan hukum. Bentuk dari perlindungan hukum ini juga banyak dapat memilih apakah ingin diselesikan melalui jalur litigasi mapun litigasi. Mengingat bahwa pengemudi ohek online mengaami banya kerugan juga, disisi lain mengalami kerugianmateril yaitu uang disisi lain rugi waktu karena waktu tersebut terbuang sia-sia, karena banyak dari masyarakat yang mengantri membutuhkan jasa pelayanan ini.

Pembatalan pesanan yang dilakukan secara sepihak oleh konsumen tentu akan merugikan pengemudi ojek online. Baik itu kerugian secara materil maupun immateril. Pengertian kerugian menurut R. Setiawan, adalah "kerugian nyata yang terjadi karena wanprestasi." Wanprestasi ini artinya tidak dipenuhinya kewajiabn oleh salah satu pihak terhadap perjanjian yang telah disepakati dalam perikatan. Adapun besarnya kerugian ditentukan dengan membandingkan keadaan kekayaan setelah wanprestasi dengan keadaan jika sekiranya tidak terjadi wanprestasi. ${ }^{22}$ Kerugian menurut Yahya Harahap, "ialah "kerugian nyata" atau "fietelijke nadeel" yang ditimbulkan perbuatan wanprestasi." ${ }^{23}$ Tidak dipenuhinya kewajiban oleh konsumen (wanprestasi) dapat disebabakan oleh dua alasan yaitu: ${ }^{24}$

a. Karena kesalahan debitor (konsumen), baik karena kesengajaan maupun kelalaian

b. Karena keadaaan memaksa (force majeure), diluar kemampuan debitor. Jadi debitor tidka bersalah.

Jadi dapat disimpulkan bahwa kerugian adalah berkurangnya jumlah harta salah satu pihak dikarenakan pelanggaran yang dilakukan oleh pihak lain. Ganti kerugian dalam hukum perdata dapat timbul dikarenakan wanprestasi akibat dari suatu perjanjian atau dapat timbul dikarenakan oleh perbuatan melawan hukum. Perbuatan melawan hukum menurut Pasal 1365 BW adalah: "Tiap perbuatan melanggar hukum, yang membawa kerugian kepada seorang lain, mewajibkan orang yang karena salahnya menerbitkan kerugian itu, mengganti kerugian tersebut."

Dalam Pasal 1246 BW menyebutkan: “ Biaya, rugi dan bunga yang oleh si berpiutang boleh dituntut akan penggantiannya, terdirilah pada umumnya atas rugi yang telah dideritanya dan untung yang sedianya harus dapat dinikmatinya, dengan tak mengurangi pengecualianpengecualian serta perubahan-perubahan yang akan diterimanya." Dari penjabaran pasal 1246 BW tersebut maka dapat disimpulkan bahwa bentuk-bentuk kerugian adalah sebagai berikut: ${ }^{25}$

1. Ongkos-ongkos atau biaya-biaya yang telah dikerluarkan.

2. Kerugiankarenakerusakan, kehilangan barangkepunyaankrediturakibatkelalaian debitur.

\footnotetext{
${ }^{22}$ R. Setiawan.(1977). Pokok-Pokok Hukum Perikatan. Bandung: Bina Cipta, hlm. 17.

${ }^{23}$ M. Yahya Harahap.(1986). Segi-Segi Hukum Perjanjian, Bandung, hlm. 66.

${ }^{24}$ Abdulkadir Muhammad.(2014). Hukum Perdata Indonesia. Bandung: PT Citra Aditya Bakti, hlm. 241.

${ }^{25}$ Meery Tjoanda, Oktober-Desember 2010, Wujud Ganti Rugi Menurut Kitab Undang-Undang Hukum Perdata, Jurnal Sasi, Vol. 16 No. 4, h. 9.
}

122 Yandri Radhi | Perlindungan Hukum Bagi... 
3. Bunga atau keuntungan yang diharapkan.

Apabila tidak dipenihunya suatu perjanjian yang menyebabkan kerugian maka berdasarkan Pasal 1236 BW: "si berutang adalah wajib memberikan ganti biaya, rugi, dan bunga kepada si berpiutang, apabila ia telah membawa dirinya dalam keadaan tak mampu untuk menyerahkan kebendaannya, atau telah tidak merawat sepatutnya guna menyelamatkannya." Selain itu, dalam Pasal 1243 juga ditambahkan sebagai berikut: "penggantian biaya rugi dan bunga karena tidak dipenuhinya suatu perikatan, barulah mulai diwajibkan, apabila si berutang, setelah lalai memenuhi perikatannya, tetap melalaikannya, atau jika sesuatu yang harus diberikan atau dibuatnya, hanya dapat diberikan atau dibuat dalam tenggang waktu yang telah dilampaukannya."

Dalam Pasal 1249 BW disebutkan pembayaran ganti rugi hanya berupa uang. "Jika dalam suatu perikatan ditentukannya, bahwa si yang lalai memenuhinya, sebagai ganti rugi harus membayar sejumlah uang tertentu, maka kepada pihak yang lain tak boleh diberikan suatu jumlah yang lebih maupun yang kurang daripada jumlah itu." Namun dalam kenyataannya, tidak hanya kerugian secara materiil yang diderita oleh pengemudi ojek online akibat dari dibatalkannya pesanan secara pihak oleh konsumen. Tetapi juga kerugian secara immateriil yang tidak dapat diganti oleh konsumen. Contohnya kerugian waktu yang digunakan untuk pergi restoran dan menunggu pesanan disiapkan.

Agar kerugian terhadap pembatalan pesanan oleh konsumen ini tidak terulang maka perlu adanya perlindungan hukum terhadap para pengemudi ojek online tersebut. Perlindungan Hukum ini dimaksudkan untuk melindungi pegemudi online bukan sebagai perlindungan pekerja berdasarkan perjanjian kerja, tetapi perlindungan sebagai pihak dalam sebuah perjanjian kemitraan. Perlindungan adalah suatu bentuk pelayanan yang wajib dilaksanakan oleh aparat penegak hukum atau aparat keamanan untuk memberikan rasa aman baik fisik maupun mental, kepada korban dan saksi, dari ancaman, gangguan, teror, dan kekerasan dari pihak manapun, yang diberikan pada tahap penyelidikan, penyidikan, penuntutan, dan atau pemeriksaan di sidang pengadilan. ${ }^{26}$

Perlindungan hukum adalah perlindungan akan harkat dan martabat, serta pengakuan terhadap hak-hak asasi manusia yang dimiliki oleh subyek hukum berdasarkan ketentuan hukum dari kesewenangan atau sebagai kumpulan peraturan atau kaidah yang akan dapat melindungi suatu hal dari hal lainnya. Berkaitan dengan konsumen, berarti hukum memberikan perlindungan terhadap hak-hak pelanggan dari sesuatu yang mengakibatkan tidak terpenuhinya hak-hak tersebut.

Masyarakat mengharapkan adanya kepastian hukum karena dengan adanya kepastian hukum akan tercipta masyarakat yang tertib, aman dan damai. Masyarakat mengharapkan adanya kemanfaatan dalam pelaksanaan penegakkan hukum. Karena hukum dapat melindungi hak dan kewajiban setiap individu dalam kenyataan yang senyatanya, dengan perlindungan hukum yang kuat akan terwujud tujuan hukum yang sempurna, yang secara umum seperti ketertiban, keamanan, ketentraman, kesejahteraan, kedamaian, kebenaran, dan keadilan.

Maka dengan itu, perlindungan hukum adalah suatu perlindungan yang diberikan terhadap subyek hukun dalam bentuk perangkat hukum baik yang bersifat preventif maupun yang bersifat represif, baik yang tertulis maupun tidak tertulis. Dengan kata lain perlindungan hukum sebagai suatu gambaran dari fungsi hukum, yaitu konsep dimana hukum dapat memberikan suatu keadilan, ketertiban, kepastian, kemanfaatan dan kedamaian.

Dalam perlindungan hukum terdapat beberapa perbedaan pendapat menurut para ahli, antara lain:

${ }^{26}$ Peraturan Pemerintah Nomor 2 Tahun 2002 Tentang Tata Cara Perlindungan Terhadap Korban dan Saksi Dalam Pelanggaran Hak Asasi Manusia yang Berat. 
1. Menurut Satjipto Raharjo mendefinisikan Perlindungan Hukum adalah memberikan pengayoman kepada hakasasimanusia yang dirugikan orang lain dan perlindungan tersebut diberikan kepada masyarakat agar mereka dapat menikmati semua hak-hak yang diberikan oleh hukum. ${ }^{27}$

2. MenurutPhilipus M.Hadjon berpendapatbahwaPerlindunganHukumadalah perlindungan akan harkat dan martabat, serta pengakuan terhadap hak-hak asasi manusia yang dimiliki oleh subyek hukum berdasarkan ketentuan hukum dari kesewenangan. ${ }^{28}$

3. Menurut CST Kansil Perlindungan Hukum adalah berbagai upaya hukum yang harus diberikan oleh aparat penegak hukum untuk memberikan rasa aman, baik secara pikiran maupun fisik dari gangguan dan berbagai ancaman dari pihak manapun. ${ }^{29}$

Suatu perlindungan dapat dikatakan perlindungan hukum apabila mengandung unsur-unsur sebagai berikut: ${ }^{30}$

1. Kepastian hukum (Rechtssicherkeit)

2. Kemanfaat hukum (Zeweckmassigkeit)

3. Keadilan hukum (Gerechtigkeit)

4. Jaminan hukum (Doelmatigkeit).

Dalam kasus tersebut jelas, konsumen yang melakukan pelanggaran pada pasal 6 Undangundnag Nomor 8 Tahun 1999 Tentang Perlindungan Konsumen yang mengatur mengenai Hakhak pelaku usaha dan pasal 1338 KUHPerdata yang membatalkan pesanan tanpa persetuuan kedua belah pihak. Untuk itu pelaku usaha wajib menuaraka hak-haknya untuk bisa mendapat ganti rugi sebagai wujud dari perlindungan huku mterhadap driver online. Namun dalam kenyatannya dilapangan, belum ada undang-undang yang yang dapat melindungi dan menjamin keamanan pengemudi ojek online yang mengalami kerugian akibat pembatalan pesanan secara sepihak oleh konsumen. Kerugian yang dialami oleh pengemudi ojek online tidak hanya berupa kerugian secara materiil saja namun juga kerugian immateriil.

Pembatalan pesanan secara sepihak oleh konsumen tentu tidak berdampak terhadap konsumen itu sendiri. Namun dampaknya akan sangat terasa bagi pengemudi ojek online tersebut. Kerugian dalam bentuk materiil tentu masih bisa diganti, tetapi kerugian immateriil berupa waktu dan tenaga yang terbuang percuma tidak akan bisa diganti. Sebagai konsumen hendaknya kita berpikir dahulu dampak dari perbuatan kita sebelum melakukan sesuatu.

\section{KESIMPULAN}

Dalam perlindungan hukum bagi pengemudi transportasi online akibat pembatalan sepihak oleh konsumen, merupakan suatu perbuatan pelanggaran hukum yang harus di pertanggungjawabkan oleh konsumen, bentuk perlindungan yang didapatkan oleh pengemudi ojek online adalah memberikan biaya ganti kerugian sebagaimana yang terdapat dalam ketentuan pasal 1365 KUHPerdata. Dalam ketentuan yang diberikan oleh undang-undang untuk perlindungan hukum kepada pengemudi ojek online harus mempunyai itakad yang baik bagi konsumen untuk mengembalikan kerugian yang sudah dialami oleh pengemudi ojek online.

\section{Daftar Pustaka}

\section{Buku}

Salim, Abbas.(2000). Manajemen Transportasi. Jakarta: PT Raja Grafindo Persada.

\footnotetext{
${ }^{27}$ Satjipto Rahardjo.(2000). Ilmu Hukum. Bandung : PT. Citra Aditya Bakti, hlm. 74.

${ }^{28}$ Philipus M. Hadjon.(1987). Perlindungan Bagi Rakyat diIndonesia. Surabaya: PT.Bina Ilmu, hlm. 25.

${ }^{29}$ Kancil CST.(1989). Pengantar Ilmu Hukum dan Tata Hukum Indonesia. Jakarta: Balai Pustaka, hlm. 102.

${ }^{30}$ Ishaq.(2009). Dasar-dasar Ilmu Hukum. Jakarta: Sinar Grafika, hlm. 43.
}

124 Yandri Radhi | Perlindungan Hukum Bagi... 
Simanjuntak, Agustinus.(2018). Hukum Bisnis Sebuah Pemahaman Integratif antar Hukum dan Praktik Bisnis. Depok: Rajawali Pers.

Soegjitna Tjakranegara.(1995). Hukum Pengangkutan Barang Dan Penumpang. Jakarta: Rineka Cipta.

Subekti, I. (1984). Hukum Perjanjian. Jakarta: PT Intermasa.

Efendi, Joenedi dan Ibrahim, Jhonny.(2018). Metode Penelitian Hukum Normatif dan Empiris. Depok: Pernadamedia Group.

Fandy Tjiptono.(2000). Manajemen Jasa, Edisi Ke-2, Yogyakarta: Andy Offset.

Subekti, II.(2001). Pokok-Pokok Hukum Perdata. Jakarta: PT. Intermasa.

Prodjodikoro, Wirjono.(2011). Azaz-Azaz Hukum Perjanjian. Bandung: Mandar Maju.

Setiawan, R.(1977). Pokok-Pokok Hukum Perikatan. Bandung: Bina Cipta.

Harahap, M. Yahya.(1986). Segi-Segi Hukum Perjanjian, Bandung.

Abdulkadir Muhammad.(2014). Hukum Perdata Indonesia. Bandung: PT Citra Aditya Bakti.

Rahardjo, Satjipto.(2000). Ilmu Hukum. Bandung : PT. Citra Aditya Bakti.

Philipus, M. Hadjon.(1987). Perlindungan Bagi Rakyat diIndonesia. Surabaya: PT.Bina Ilmu.

Kancil CST.(1989). Pengantar Ilmu Hukum dan Tata Hukum Indonesia. Jakarta: Balai Pustaka. Ishaq.(2009). Dasar-dasar Ilmu Hukum. Jakarta: Sinar Grafika.

\section{Jurnal}

Dian Mandayani Ananda Nasution, April 2018, Tinjauan Hukum Terhadap Layanan Transaksi dan Transportasi Berbasis Aplikais Online, Resam Jurnal hukum, Vol. 4, No. 1.

Meery Tjoanda, Oktober-Desember 2010, Wujud Ganti Rugi Menurut Kitab Undang-Undang Hukum Perdata, Jurnal Sasi, Vol. 16 No. 4.

\section{Peraturan Perundang-Undangan}

Kitab Undang-Undang Hukum Perdata.

Undang-undnag No. 8 Tahun 1999 Tentang Perlindungan Konsumen.

Undang-Undang No.22 Tahun 2009 tentang Lalu Lintas dan Angkutan Jalan.

Undang-Undang Nomor 7 Tahun 2014 tentang Perdagangan.

Peraturan Pemerintah Nomor 2 Tahun 2002 Tentang Tata Cara Perlindungan Terhadap Korban dan Saksi Dalam Pelanggaran Hak Asasi Manusia yang Berat.

\section{Internet}

Syarat dan Ketentuan Penggunaan GoFood, Diakses pada tanggal 22 April 2020, Website: gojek.com/terms-and-condition/ 